\title{
Conditions of Service of Teachers as Correlates of Motivation in Secondary Schools in Ado and Efon Local Government Areas, Ekiti State
}

\author{
Afolabi, Comfort Yemisi \\ Government House and Protocol Department, \\ Office of the Wife of Ekiti State Governor, \\ Government House Grounds, \\ Ado Ekiti, Nigeria \\ E-mail: afolabicomfortyemisi@yahoo.com
}

Received: 17-05- 2013

Accepted: 27-06- 2013

Published: 01-07- 2013

doi:10.7575/aiac.ijels.v.1n.1p.89

URL: http://dx.doi.org/10.7575/aiac.ijels.v.1n.1p.89

\begin{abstract}
This paper examined the relationship between conditions of service of teachers and their motivation in secondary schools in Ado and Efon Local Government Areas in Ekiti State, Nigeria. The sample for the study consisted of 500 teachers who were selected from the 18 secondary schools in the two Local Government Areas used for the study. Due to the fact that secondary schools in Ado Local Government Area were more than the secondary schools in Efon Local Government Area, stratified proportional random sampling was used to select the sample for the study. A self-designed questionnaire was used to collect data for the study. The data collected were analysed using Pearson product moment correlation. The hypotheses raised were tested at 0.05 level of significance. The study revealed significant relationship between teachers' posting, training, workload and their motivation while there was no significant relationship between discipline of teachers and their motivation. Based on the findings, it was recommended that conditions of service in secondary schools should be improved and made attractive to teachers to enhance their motivation on the job.
\end{abstract}

Keywords:Conditions of service, Staff motivation, Teachers, Posting, Training, Discipline, Workload, Secondary schools

\section{Introduction}

Nigeria has been able to provide the manpower needs in almost every sphere of our national and international existence through western education. This achievement cannot be isolated from the efforts of professional teachers, who since the history of formal education in Nigeria appear to have nothing substantial to show regarding the rewards of their efforts in contributing to build a virile nation.

In spite of this, teachers' importance in educational process is great. Teachers are very vital for successful educational systems. Adedeji (1998) and Oguntoye (2007) agreed that teachers are very important to the success of the school system in achieving its goals and objectives. Fasanmi (1996) opined that the standard of education in any country cannot be above the standard of its teachers. Lornarh, Sirima and Poipoi (2010) agreed that job satisfaction is essential to continuing growth of educational system around the world and that teachers are crucial elements of educational opportunity structures. Teachers must be ready to discharge their duties and obligations in order to achieve successful, effective and efficient teaching and learning processes in the educational system (Adedeji, 1998 and Omotayo, 2007). According to Fafunwa (1980), there is no greater factor for the social economic and political advancement than a good educational system.

Teachers' motivation is equally important for any educational system to achieve its goals and objectives. Motivation could be seen as that motives that energise people or staff to work harder. Motivation could be defined as a process of arousing enthusiasm in individual so that he/she can perform his/her duties with pleasure and high interest in pursuance of the organisational and his personal goals. According to Oyedeji (1998), motivation is one of the ways of making workers to put forth their best efforts in an efficient and effective manner in order to achieve organisational objectives. Bennell (2004) noted that motivation refers to the psychological process that influences individual's behaviour with respect to the attainment of workable goals and tasks. Motivation is therefore that inner drive that makes workers to work more without regret. On the other hand, Dornyei (2005) defines de-motivation as specific external forces that reduce or diminish motivational basis of a behavioural intention or an ongoing action. This implies that teachers could either be motivated or de-motivated on the job.

Teachers' conditions of service appears unattractive to the teachers. Many teachers have raised their voices severally against their conditions of service. Teachers have be-mourned the way they have been treated shabbily by government, the school authority, the students they teach and even the parents of their students. Experience has shown that some parents have gone to the school to beat up their wards' teachers on flimsy excuses of maltreatment of their children/wards by such teachers. It is worthy of note that due to the poor conditions of service and inadequate motivation for teachers, their performances on the job have fallen. It seems that many of them have also decided to seek 
for their fortune elsewhere. It is observed that teachers are not well treated on the job. They seem not well motivated enough to do the job as they should. This has led to brain-drain in our national life, which has inevitably led to the production of semi-illiterates in educational institutions. Due to teachers' poor conditions of service, they do not stay long in the teaching profession. It appears that they see teaching as a stepping stone to obtaining higher-paying job elsewhere due to poor conditions of service of teachers. In this vein, Adekunle (1987) in buttressing the fact that teachers are ill-treated claimed that it is a pity that teachers who are to see to the total development of the child physically, morally, spiritually and intellectually are treated as underdogs.

Furthermore, Selemani-Meke (2013) opined that poor allowances that teachers receive and poor conditions of service have contributed to lack of motivation of teachers to effectively implement at all levels. Moreover, teachers seem not motivated to work hard. Teacher's conditions of service such as posting of teachers, Training, discipline of teachers, duties and obligations expected of teachers/workload appear very vital in the teaching and learning processes. The conditions of service of teachers on the job appear poor. According to Aina (1992), there are arrears of salaries unpaid and arrears of benefits and allowance suspended or forgotten and inflation rob teachers of their purchasing power. Many teachers find themselves in life-chocking frustration. Teachers seem unpaid for months and therefore cannot teach on empty stomachs.

Fasanmi (1996) posited that during every economic downturn, the teachers are the first to suffer from nonpayment of salaries. Mkpa (1990) claimed that salaries had been paid to teachers long after other civil servants had received theirs. Fringe benefits have been reluctantly granted to teachers. Evidences abound that many teachers did not get their pensions and gratuities years after retirement. Teachers' promotion, salary and its prompt payment are vital for the success of the educational system. Alarm and Farid (2011) found out that most teachers were not satisfied with their salaries and this has affected their teaching. Teachers want more incentives and rewards on the job. Alarm and Farid (2011) discovered in their studies that only $24 \%$ of the teachers used for the study agreed that they had reasonable salary while $66 \%$ said that their salary was not reasonable and $30 \%$ agreed that they received their salary on time while $60 \%$ disagreed. Pihie and Elias (2004) found out that teachers did not favour teaching because of low salary, lack of promotion opportunities, and heavy workload.

Training has been seen as an important aspect of teachers' conditions of service. In - service training equipped teachers for effectiveness on the job. Bennell and Ntagaramba (2008) noted that well-trained teachers are likely to be better motivated than poorly training teachers. If teachers are not adequately prepared, this makes it much more difficult for them to cope, especially during the early stages of their career which could have negative impact on their motivation. The provision of regular, high quality in-service training is essential in order to ensure the attainment of consistently high teaching standards. They added that $75 \%$ of teachers rated the current availability of in-service training as poor and only $1 / 3$ of the teachers attended in-service training during the previous year. This further shows that teachers see inservice training as very important want to enjoy it more regularly on the job.

Discipline of teachers is also an important aspect of teachers' conditions of service. The Education Law (1978) noted that teachers who erred would be disciplined by the Teaching Service Commission. Discipline, like verbal warnings and issuance of queries could be administered on erring teachers by their school heads. However, the Teaching Service Commission disciplines teachers for offences like immorality and general misconduct such as fraud, dishonest conduct of examinations, falsification of records, bribery and corruption. Weinstein and Mignano (1993) defined discipline as an important contributing factor to developing a caring community. Sonn (2002) noted that three pillars form the basis for discipline such as respect for authority figure, a system of reward/punishment and a set of consequences. Pienaar (2003) believed that discipline does not motivate. Van Wyk (2000) opined that punishment is usually viewed as negative, since it is designed to force an individual to remove or clean some unwanted cognitive or affective behaviour.

Authors disagree on the relationship between staff conditions of service and their motivation on the job. Some authors see conditions of service as predictors of teachers' motivation. Others have divergent views. Ladd (2009) reported that working conditions emerge as highly predictive of teachers' stated intentions and motivation to remain in schools or leave their schools. She added that teachers' perceptions of their working conditions are also predictive of departure rates and students' achievement but the predictive power is far lower.

Bennell (2004) and Bennell and Mukyanuzi (2005) noted that increasing hours of work, larger class sizes, more subjects and constantly changing curricula have been cited as major de-motivators in many countries. Bennel and Ntagaramba (2008) noted in a study that the workload norm in government secondary school is 24 periods per teacher out of a 40 period school week. According to them, this norm is widely adhered to, but teachers in most secondary schools teach for only four days a week. Teachers are over burdened, therefore, it is important to try to reduce the workload of teachers as quickly as possible. This implies that the teachers could not teach all the periods allocated to them daily/weekly, because they felt the workload was too heavy. The work and living environment for teachers appears uncomfortable. This seems to lower their self esteem which is generally de-motivating.

Moreover, Kadzamira (2006) claimed that teachers refuse to be deployed to schools in certain areas. This implies that posting is vital to their job satisfaction and motivation. According to Bennell and Ntagaramba (2008), the uneven posting/deployment of teachers is a major incentive issue. The main reasons for this situation are the unattractive working and living conditions in many rural areas. Hence, staff imbalances across schools, sectors and districts are particularly acute among secondary school teaching force. 
Bishay (1996), Thoonen, sleegers, Oort, Peetsma and Geijsel (2001) and Rashaeed and Sarwar (2010) had contrary views to Bennell (2004), Bennell and Mukyanuzi (2005), Bennell and Ntagaramba (2008) and Ladd (2009) on the relationship that exist between teachers' conditions of service and their motivation. Bishay (1996) opined that pay incentives had been found to be unsuccessful in increasing teachers' motivation. Theoren, Oort, Peetsma and Geijsel (2001) found out that teachers' sense of self-efficacy or esteem appeared to be the most important motivational factor for explaining teachers' learning and teaching practices. Rasheed, Aslam and Sarwar (2010) discovered that compensation and benefits are important factors but some intangible motivators like job design, work environment, feedback, recognition and empowerment or decision making participation are also the potential factors for motivating teachers. In view of these controversies, the present study would therefore investigate the relationship between teachers' conditions of service and motivation. In this study, conditions of service are limited to posting of teachers, training, discipline of teachers and their workload.

\section{Purpose of the Study}

The purpose of this study was to investigate the relationship between teachers' conditions of service and their motivation on the job. This study also investigated the relationship between teachers posting, training, discipline, workload and their motivation.

\section{Research Hypotheses}

The following research hypotheses were formulated for the study:

1. There is no significant relationship between teachers' conditions of service and their motivation.

2 There is no significant relationship between posting of teachers and their motivation.

3 There is no significant relationship between training of teachers and their motivation.

$4 \quad$ There is no significant relationship between discipline of teachers and their motivation.

$5 \quad$ There is no significant relationship between teachers' workloads and their motivation.

\section{Methodology}

The study is descriptive research of the survey type. The population consisted of all 1,415 teachers in public secondary schools in Ado and Efon Local Government Areas of Ekiti State. There are 1,253 teachers in Ado and 162 in Efon. The sample for the study consisted of 500 teachers selected from 15 out of 18 schools in the two Local Governments. Sixty five (65) teachers were selected from Efon while four hundred and thirty five (435) teachers were selected from Ado. Stratified proportional random sampling was used to select the sample used for the study.

A self-designed questionnaire, tagged "Questionnaire on Teachers' Conditions of Service and Motivation" (QTCSM) was used to collect the necessary data for the study. Research experts in Tests and Measurement and Educational Management in Ekiti State University validated the instrument. The test-retest method was used to test the reliability of the instrument and the reliability coefficient stood at 0.79 . Pearson Product Moment Correlation was used to analyse the data collected. The hypotheses formulated were tested at 0.05 level of significance.

\section{Results}

Hypothesis 1: There is no significant relationship between conditions of service of teachers and their motivation.

Table 1. Correlation of teachers' conditions of service and their motivation

\begin{tabular}{|l|c|c|c|c|c|}
\hline \multicolumn{1}{|c|}{ Group } & $\boldsymbol{N}$ & $X$ & $\boldsymbol{S D}$ & $\boldsymbol{r}$-cal & r-table \\
\hline Conditions of service of teachers & 500 & 86.35 & 6.44 & & \\
\cline { 1 - 5 } Motivation & 500 & 162.46 & 10.69 & 1.14 & 1.96 \\
\hline
\end{tabular}

Table 1 shows that $r$-cal $(0.391)$ is greater than r-table $(0.195)$ at 0.05 level of significance. The null hypothesis is rejected. Therefore, there is significant relationship between teachers' conditions of service and their motivation.

Hypothesis 2: There is no significant relationship between posting of teachers and their motivation.

Table 2. Correlation of posting of teachers and their motivation

\begin{tabular}{|l|c|c|c|c|c|}
\hline \multicolumn{1}{|c|}{ Group } & $\boldsymbol{N}$ & $X$ & $\boldsymbol{S D}$ & $\boldsymbol{r}$-cal & r-table \\
\hline Posting of teachers & 500 & 12.94 & 2.04 & & \multirow{2}{*}{0.196} \\
\hline Motivation & 500 & 162.46 & 10.69 & 0.507 & 0.196 \\
\hline
\end{tabular}

$$
\rho<0.05
$$

Table 2 shows that $r$-cal $(0.507)$ is greater than $r$-table $(0.195)$ at 0.05 level of significance. The null hypothesis is rejected. Therefore, there is significant relationship between posting of teachers and their motivation.

Hypothesis 3: There is no significant relationship between training of teachers and their motivation.

Table 3. Correction of teachers' training and their motivation

\begin{tabular}{|l|c|c|c|c|c|}
\hline \multicolumn{1}{|c|}{ Group } & $\boldsymbol{N}$ & $X$ & $\boldsymbol{S D}$ & $\boldsymbol{r}$-cal & r-table \\
\hline Training of teachers & 500 & 17.33 & 1.68 & & \\
\cline { 1 - 4 } Motivation & 500 & 162.46 & 10.69 & 0.497 & 0.195 \\
\hline
\end{tabular}


Table 3 shows that $r-$ cal $(0.479)$ is greater than $r$ - table of $(0.195)$ at 0.05 level of significance. The null hypothesis is rejected. It implies that there is significant relationship between training of teachers and their motivation.

Hypothesis 4: There is no significant relationship between discipline of teachers and their motivation

Table 4. Correlation of teachers' discipline and their motivation

\begin{tabular}{|c|c|c|c|c|c|}
\hline Group & $N$ & $X$ & $S D$ & $r$-cal & r-table \\
\hline Discipline of teachers & 500 & 15.97 & 2.74 & \multirow[b]{2}{*}{0.042} & \multirow[b]{2}{*}{0.195} \\
\hline Motivation & 500 & 162.46 & 10.69 & & \\
\hline
\end{tabular}

$\rho>0.05$

The null hypothesis is accepted since $r$ - cal (0.042) is lower than $r$ - table $(0.195)$ at 0.05 level of significance. This implies that there is no significant relationship between discipline of teachers and their motivation.

Hypothesis 5: There is no significant relationship between teachers' workload and their motivation.

Table 5. Correlation of teachers' workload and their motivation

\begin{tabular}{|l|c|c|c|c|c|}
\hline \multicolumn{1}{|c|}{ Group } & $\boldsymbol{N}$ & $X$ & $\boldsymbol{S} \boldsymbol{\text { SD }}$ & ral & r-table \\
\cline { 1 - 4 } Teachers' workload & 500 & 16.87 & 2.63 & & \\
\cline { 1 - 4 } Motivation & 500 & 162.46 & 10.69 & \multirow{2}{*}{0.483} & \multirow{2}{*}{0.195} \\
\hline
\end{tabular}

$$
\rho<0.05
$$

The relationship between teachers' workload and their motivation is moderately high, positive and statistically significant at 0.05 level of significance since t-cal is greater than r-table. This implies that the null hypothesis is rejected.

\section{Discussion}

The study showed a significant relationship between teachers' conditions of service and their motivation. This explains the importance that teachers attach to attractive conditions of service which led to comparison of their conditions of service to those of other disciplines. This implies that teachers' conditions of service and motivation have considerable influence on each other. This agrees with Ladd (2009), who saw conditions of service as predicators of teachers' motivation, and Bennell (2004), Bennell and Mukyanuzi (2005) who saw certain unpleasant aspects of teachers' conditions of service as de-motivators. This study also agrees with Selemani-Meke (2013) who noted that poor conditions of service of teachers have contributed to their lack of motivation.

The study revealed a significant relationship between posting of teachers and their motivation. This means that posting of teachers is also important to teachers' motivation. This explains why majority of teachers are always not happy when they are posted to rural areas or when their posting are too regular or out of the town where their immediate family members are domiciled. This agrees with Kadzamira (2006) who claimed that teachers refuse to be deployed to schools in certain rural areas.

The study showed that there was significant relationship between training of teachers and their motivation. This means that on-the-job training of teachers has impact on teachers' motivation. This explains the reason why teachers bemoan their inadequate training. The finding of this study agrees with Bennell and Ntagaramba (2008) who submitted that well trained teachers are likely to be better motivated. The finding is in contrast with Theoren, Oort, Peetsma and Geijsel (2001) and Selemani-Meke (2013).

The finding of the study however revealed that there was no significant relationship between discipline of teachers and their motivation. This implies that discipline of teachers do not predict teachers' motivation. This explains the fact that no teacher/staff likes to be disciplined even when it was a fact that such a teacher/staff actually committed an offence that merited the discipline. The study agrees with Pienaar (2013) who believed that discipline does not motivate.

The study showed a moderately high, positive significant relationship between teachers' workload and their motivation. This implies that teachers' workload is key and highly important to teachers' motivation. This explains the fact that teachers with too heavy workload would have so much to do that he/she may not enjoy the job and this could lead to demotivation. The finding of the study supports the works of Bennell (2004), Pihie and Elias (2004) and Ladd (2009).

\section{Conclusion and Recommendations}

Based on the findings of this study, it is concluded that significant relationship existed between teachers' conditions of service and their motivation. It is therefore, recommended that teachers' conditions of service should be improved and made attractive to teachers in secondary schools in Ado and Efon Local Government Areas. The study revealed that the posting, training and workload of teachers correlated significantly with their on the job motivation. Based on these findings, it is recommended that government should look into irregular posting of teachers. The welfare of teachers and their families should also be considered when deploying teachers from one school to the other. Regular in- service training should be organized for teachers to enhance their motivation. Well trained teachers are likely to teach the students adequately and effectively. Government should employ more teachers so that the workload of teachers would be reduced. Teachers should also endeavour to energize themselves and be motivated on the job. However, the study revealed that there was no significant relationship between discipline of teachers and their motivation. It is therefore, recommended that teachers should be given adequate warnings before severe discipline is meted out to persistent erring teachers. Teachers should also be given ample opportunity to fair hearing and defense before being disciplined. They 
should also be part of decision making on discipline procedures for erring teachers which would make the affected teachers know that they actually merited the punishment meted out to them.

\section{References}

Adedeji, S. O. (1998). The relationship between resource utilisation and academic performance in vocational education in Osun State secondary schools. An unpublished Ph.D. thesis, University of Ibadan, Nigeria.

Adekunle, A. (1987). The teaching professions. Sunday Sketch. December 7. 10.

Aina, O. (1992). Personnel management in Nigeria: A work-centred approach. Ikeja, Lagos: F. Communications.

Alarm, M. T. \& Farid, S. (2011). Factors affecting teachers' motivation. International Science. 2(1): 298-304.

January.

Bennell, P. (2004). Teacher motivation incentives in Sub-Saharan Africa and Asia. Brighton: Knowledge and Skills for Development.

Bennell, P. \& Ntagaramba, J. (2008). Teacher motivation and incentives in Rwanda: A situational analysis and recommended priority actions. An unpublished mimeograph, National University of Rwanda.

Bennell, P. \& Mukyanuzi, F. (2005). Is there a teacher motivation crisis in Tanzania? Tanzania: Dar es Salaam: HR

Consult.

Bishay, A. (1996). Teacher motivation and job satisfaction: A study employing the experience sample method. Journal of Undergraduate Science. 3:14-154.

Dornyei, B. (2005) in Sadruddin, M. M. (2012). Discipline-improving classroom management through action: A professional development plan. Journal of Management Sciences. 6 (1): 23—42. January—June.

Education Law Cap 34 (1978). Teachers' service manual regulations. Lagos, Nigeria.

Fafunwa, A. B. (1980). New perspectives in African Education. London: Macmillan Education Limited and Basing Stroke.

Fasanmi, F. O. (1996). Brain-drain from the teaching profession: Implication for the administration of teachers. Journal of Educational Research and Evaluation (JOEREV); OSUA. 1(2): 266-269.

Kadzamira, E, C. (2006). Teacher motivation and incentives in Malawi: University of Malawi. Centre for Educational Research and Training. July. 5.

Lornah, C.; Sirima, N. \& Poipoi, M. W. (2010). Perceived factors influencing public secondary school teachers' job satisfaction in Busia district, Kenya.

Ladd, H. (2009). Teachers' perceptions of their working conditions: How predictive of policy-relevant outcomes.

Working Paper 33; National Centre for Analysis of Longitudinal Data in Education Research. December.

Mkpa, M. A. (1990). Foundation of education. Zaria, Nigeria: Africana-Fep. Publishers Ltd.

Oguntoye, A. O. (2002). Motivation as correlate of teachers' job performance in secondary schools in Ogun State. An unpublished M.Ed. thesis, University of Ado-Ekiti.

Omotayo, K. A. (2007). Teacher quality: An imperative for achieving a worthwhile UBE in Nigeria. Journal of

Educational Foundations and Management. 5(1): 85-91.

Oyedeji, N. B. (1997). Management in education: Principle and practice. Lagos: ARAS Publishers.

Pienaar, G. (2003). A different approach to classroom discipline problem. Educare. 32(1): 261-274.

Pihie, Z. A. L. \& Elias. H. (2004). Improving the teaching profession through understanding education's self-

motivation. Pakistan Journal of Psychological Research 19 (1\&2) 25-35.

Rasheed, M. I.; Aslam, H. D. \& Sarwar, S. (2010). Motivational issues for teachers in higher education: A critical case of IUB. Journal of Management Research. 2(3).

Selemani-Meke, E. (2013). Teacher motivation and implementation of continuing professional development programmes in Malawi. Anthropologist. 15(1):107-115.

Sonn, B. (2002). Discipline in schools: Discipline in a culture of human right. Cape Town: Via Africa.

Thoonen, E. E. J.; Sleegers, P. J. C.; Oort, F. J.; Peetsma, T. T. D. \& Geijsel, F. P. (2011). How to improve teaching practice: The role of teachers' motivation, organisational factors and leadership practices. SAGE Journals of Educational Administration Quarterly. Feb 28th. 47(3): 496-536.

Van Wyk, E. R. (2000). Positive discipline: A new approach to discipline. D.Ed. dissertation, University of South Africa, Pretoria.

Weinstein, K. \& Mignano, L. (1993). Strategies and techniques in teaching. New York: Harper \& Row. 